\title{
RADIO KOMUNITAS: MEDIA RAKYAT BERBASIS PEMBERDAYAAN
}

\author{
Juniawati
}

\begin{abstract}
Abstrak
Kehadiran radio mampu membantu pemerintah dan masyarakat lebih berdaya dan maju dalam segala aspek kehidupan. Tidak hanya itu, radio sudah menjadi industri yang mampu menopang pendapatan negara. Peran lain yang tidak pernah luput diberikan oleh radio adalah radio telah mampu membangun kualitas pembangunan manusia baik dari aspek informasi dan pendidikan, kesehatan maupun dari asepk hiburan. Radio komunitas berjalan mengikuti keterbatasan yang dimiliki masyarakat, adapaun tuntunan atau aturan yang disebut di atas dikemudian hari baru disentuh atau diperhatikan, itupun boleh jadi dikarenakan ada pihak luar yang membantu. penyiaran radio yang paling sederhana telah hadir di negeri ini dan telah mampu menjelaskan kepada dunia bahwa radio komunitas bukan sekadar siaran biasa. Tapi bisa mewarnai kehidupan berbangsa dan bernegara di Indonesia. Kehadiran radio Komunitas yang jauh dari kota mapun hiruk-pikuk dunia luar, tertnyata telah menjadi sorotan yang besar dari pemerintah.
\end{abstract}

Kata Kunci: kelompok, informasi, penyiaran

\section{A. Latar Belakang}

Radio adalah salah satu medium rakyat yang paling dekat (popular) dengan masyarakat Indonesia khususnya bagi keluarga. Ini telah berlangsung sejak zaman kemerdekaan hingga kemerdekaan diraih. Selain memiliki kekuatan strategis ekonomis, sebab radio merupakan media yang murah, secara fungsional, radio sangat fortable atau dapat dibawa kemana-mana dan harganya dapat menjangkau semua lapisan lapisan masyarakat.
Sebagaimana kita ketahui radio mempunyai beberapa kelebihan Morrisan (2008), antara lain:

* Radio mempunyai kekuatan tersendiri dibanding media lain yang ada saat ini. Keistimewaan tersebut terletak pada daya imajinasi yang dibangun kepada pendengar. Kelebihan dari siifatnya yang Auditif. untuk didengarkan, untuk telinga, untuk dibacakan atau disuarakan. 
* Transmisi, proses penyebaran melalui pemancar (transmisi)

* Sekilas. Tidak bisa diulang. Karenanya harus jelas, sederhana, dan sekali ucap langsung dimengerti.

* Bahasa sehari-hari (Spoken Language). Menggunakan bahasa tutur atau kata-kata yang biasa diucapkan dalam obrolan seharihari (spoken words). Kata-kata yang dipilih mesti sama dengan kosa kata pendengar agar dapat langsung dimengerti.

Dari sifat radio yang mudah diperoleh karena harganya yang makin terjangkau, radio juga merupakan sarana yang membantu masyraakat di berbagai pelosok daerah untuk mengetahui informasi yang terjadi sekaligus menjadi hiburan murah.

Radio sebagai bagian dari media massa yang medunia, mempunyai pengaruh yang besar bagi berkembangnya suatu negara. Hal ini telah dibuktikan di berbagai belahan dunia, tidak terkecuali Indonesia. Keberadaan radio di Indonesia telah dekat dengan kehidupan masyarakat baik sebelum kemerdekaan dan terlebih setelah kemerdekaan. Sebab setelah masa reformasi tahun 1998, siaran radio diberi peluang untuk berkembang di daerah

Sesungguhnya, kehadiran radio mampu membantu pemerintah dan masyarakat lebih berdaya dan maju dalam segala aspek kehidupan. Tidak hanya itu, radio sudah menjadi industri yang mampu menopang pendapatan negara. Peran lain yang tidak pernah luput diberikan oleh radio adalah radio telah mampu membangun kualitas pembangunan manusia baik dari aspek informasi dan pendidikan, kesehatan maupun dari asepk hiburan.

Lebih jelas lagi ketika pengaturan radio di Indonesia berlandaskan kepada kondisi masyarakat yang, sehingga secara yuridis kegiatan penyiaran radio dapat kita lihat telah diatur oleh Komisi Penyiaran Indonesia melalui Undangundang Penyiaran no 32 tahun 2002. Dalam UU penyiaran no 32 tahun 2002 ini menyebutkan jelas terdapat beberapa bentuk penyelenggaraan penyiaran yang ada di Indonesia yaitu:

1. Radio Publik. Lembaga penyiaran yang berbadan hukum yang didirikan oleh negara, bersifat independen, netral (tidak komersial) dan berfungsi memberikan pelayanan untuk kepentingan masyarakat (UU Penyiaran no 32 tahun 2002 pasal 14) 
2. Radio dan Televisi swasta. Lembaga penyiaran yang bersifat komersial berbadan hukum Indonesia. Bidang usahanya, jasa siaran baik Radio maupun TV. (UU Penyiaran no 32 tahun 2002 pasal 16)

3. Radio dan Televisi Komunitas. Lembaga penyiaran yang berbadan hukum, didirikan oleh suatu komunitas tertentu, bersifat independen, dan tidak komersial dengan daya pancar rendah dan jangkauan wilayah terbatas dan melayani kepentingan kemunitasnya. (UU Penyiaran no 32 tahun 2002 pasal 21)

Dari definisi yang digariskan oleh Undang-undang Penyiaran no 32 tahun 2002 di atas jelas bahwa kepentingan yang utama dari penyelenggaraan siaran media elektronik baik Televisi maupun radio adalah mengutamakan masyarakat sebagai subjek mapun objek penyiaran. Dengan adanya pengaturan lembaga penyiaran dalam Undang-undang Penyiaran no. 32 tahun 2002 ini telah memberikan peluang dan kesempatan yang besar kepada masyarakat di daerah untuk mendirikan lembaga penyiaran yang sesuai dengan watak, budaya dan tatanan nilai yang ada dalam masyarakat setempat.

\section{B. Mengenal Radio Komunitas}

Tak banyak dari kita yang tahu apa dan bagaimana rangka kerja radio komunitas. Sepintas dari pengenalan di atas mengenai penyiaran yang ada di Indonesia, radio komunitas merupakan bagian dari salah satu lembaga penyiaran yang juga ikut berpartisipasi aktif dalam sistem pernyiaran di Indonesia.

Seperti di sebutkan dalam Undang-Undang Penyiaran no 32 tahun 2002, bahwa radio komunitas merupakan bagian dari sistem penyiaran atau lembaga penyiaran yang didirikan secara swadaya oleh sekolompok orang atau komunitas tertentu.

Lembaga penyiaran yang berbadan hukum, didirikan oleh suatu komunitas tertentu, bersifat independen, dan tidak komersial dengan daya pancar rendah dan jangkauan wilayah terbatas dan melayani kepentingan kemunitasnya. (UU penyiaran no 32 tahun 2002 pasal 21)

Istilah radio komunitas merujuk pada pemilikan dan wilayah orientasi yang melokal sebagai antitesis radio swasta yang meluas dan berjaringan. Istilah ini kemudian lebih sering dipakai karena dirasa santun dan akrab secara internasional (Ismahfudi, MH, 2007). Dalam tulisan Ismahfudi, MH 92007) yang merujuk dari pengertian yang diberikan oleh lembaga PBB UNESCO bahwa radio komunitas adalah radio yang 
dioperasikan di komunitas, untuk komunitas,tentang komunitas dan oleh komunitas itu sendiri. Komunitas dapat diacu berdasarkan kesamaan geografis atau minat yang sama di anatar kelompok orang.

Selaras dengan definisi di atas, menurut Agus Sudibyo (2004) community broadcasting didefinisikan sebagai siaran yang diselenggarakan oleh kelompok masyarakat tertentu dengan tujuan tertentu dan merujuk pada aspek geografs atau lokalitas.

Apabila menoleh pada aspek sejarah, kehadiran radio komunitas Era 1970-an radio Komunitas secara yuridis juga sudah disebut melalui PP no 55 tahun 1970 yang menyebut radio komunitas sebagai radio non komersial.

Dari aturan ini maka muncullah radio-radio komunitas. Seperti di perguruan tinggi, muncul radio Tarumanegara, radio UI, radio UKI, radio USU Medan, radio MSTRI Jakarta, radio Gema Mahasiswa Unsoed Purwokerto. Selain itu, di luar kampus, muncul radio dakwah seperti radio Assafi'iyah Jakarta dan radio Ihtus Semarang (Agus Sudibyo 2004).

Keberadaan radio komunitas pasca Soeharto hadir sebagai alternatif penyiaran yang lebih populis dan jauh dari pretensi manipulasi kepentingan oleh pengelola.Sehingga pertumbahan radio komunitas diperkirakan oleh Erlinus Thahar Ismahfudi, MH, (2007) mencapai 680 stasiun.

Radio komunitas juga memiki karakter dan ke khasan tersendiri yakni hubungan langsung dan interaktif antara lembaga penyiaran dengan komunitas dan adanya partisipasi anggota komunitas dalam perencanaan program, produksi, pembiayaan, dn dalam evaluasi kerja lembaga penyiaran.

Di bawah ini untuk lebih tabel dimana secara jelas dapat kita lihat perbedaan radio komunitas dengan 2 jenis radio lainnya yang dikemukakan oleh Ismahfudi, MH (2007) sebagai berikut :

\section{Perbedaan radio Komunitas dengan Radio Publik}

\begin{tabular}{|l|c|c|}
\hline Karakteristik & $\begin{array}{c}\text { Radio } \\
\text { Komunitas }\end{array}$ & $\begin{array}{c}\text { Radio } \\
\text { Publik }\end{array}$ \\
\hline Tipe wilayah & Spesifik & Umum \\
\hline Wilayah siaran & Lokal & Nasional \\
\hline $\begin{array}{l}\text { Sifat } \\
\text { Kepentingan }\end{array}$ & Primordial & Universal \\
\hline
\end{tabular}

Perbedaan Radio Komunitas dengan Radio Komersial

\begin{tabular}{|l|l|l|}
\hline Karakteristik & $\begin{array}{l}\text { Radio } \\
\text { Komunitas }\end{array}$ & $\begin{array}{l}\text { Radio } \\
\text { Komersial }\end{array}$ \\
\hline Tujuan & Non-Profit & Profit \\
\hline Keputusan & Ditentukan & Ditentukan \\
& Pengelola & pemilik \\
\hline Pemilikan & Kolektif & Individu \\
\hline
\end{tabular}


Ismahfudi, $\quad \mathrm{MH} \quad$ (2007) menyebutkan radio komunitas dapat didirikan berdasarakan beberapa hal utama:

1. Jaminan keberadaan komunitas secara permanen di lingkup batas geografis tertentu yang bersedia aktif dalam mengelola radio radio secara mandiri

2. Peluang partisipasi tiap individu di komunitas secara setara baik dalam kepemilikan, produksi siaran, maupun selaku pihak pendengar yang harus terlayani hak dan kepentingannya.

Lebih lanjut Ismahfudi, MH (2007) juga menyebutkan bahwa prinsip dari lembaga penyiaran komunitas adalah partisipasi. Hal ini merujuk kepada arahan dari badan dunia PBB UNESCO yang memandang partisipasi dalam beberapa kelompok:

1. Pembuatan program

Secara maksimal pembuatan program siaran radio komunitas melibatkan pendengar komunitasnya, sejak perencanaan hingga pengemasan. Contoh dengan melibatkan pendengar sebagai programer, penyiar dan pewawancara termasuk menjadi pihak yang diwawancarai.
2. Partisipasi individu dan kelompok sebagai pembawa acara atau penyiar.

Dalam hal ini radio komunitas diharapkan bisa menjadi titik temu antar warga dibimbing secara teknis oleh pengelola radio

3. Partisipasi individu dalam evaluasi acara.

Pada bagian ini metode partisipasi dimaksimalkan selain melalui surat, juga memaksimalkan telepon interaktif untuk memperoleh masukan dan kritik serta mengadakan dialog terbatas dengan peserta terpilih dengan waktu yang ditentukan.

Selain itu, penyiaran komunitas yang berada di suatu komunitas tertentu ini aktifitasnya tidak hanya berada di dalam studio melainkan memungkin siaran terjadi di luar studi. Untuk melihat apa saja persoalan yang diangkat radio komunitas pada umumnya berdasarkan keadaan yang terjadi di masyarakat, seperti berikut ini:

1. Kesenjangan tingkat kesejahteraan ekonomi dan tingkat pendidikan termasuk fenomena kemiskinan

2. Diskriminasi pengambilan keputusan, peradilan dan tersumbatnya peluang menduduki jabatan publik 


\section{Radio Komunitas dan Perubahan Sosial}

Masyarakat dalam pandangan ahli sosiolog seperti Emile Durkheim adalah kenyataan objektif individuindividu yang merupakan anggotaanggotanya. Lainnya dengan Karl Marx yang memandang masyarakat sebagai struktur yang terdapat ketegangan sebagai akibat pertentangan antarkelas sosial sebagai akibat pembagian nilai-nilai ekonomi yang tidak merata di dalamnya. Selo Sumarjan pula mendefinisikan masyarakat sebagai orang-orang yang hidup bersama dan menghasilkan kebudayaan.

Dari beberapa pandangan di atas, disimpulkan bahwa masyarakat adalah sekelompok manusia yang bertempat tinggal di daerah tertentu dalam waktu yang relatif lama, memiliki norma-norma yang mengatur kehidupannya menuju tujuan yang dicita-citakan bersama ( Elly M. Setiadi dan Usman Kolip, 2011)

Sebagaimana kita ketahui bahwa media dan masyarakat merupakan dua institusi yang berbeda namun saling mempunyai keterkaitan satu dengan yang lain.

Hal tersbut mengikuti fungsi media yang luas, Dominick (2001) menyebutkan mengandung beberapa fungsi yaitu:

1. Fungsi Pengawasan
Fungsi pengawasan terjadi manakala media memberikan informasi mengenai keadaan sekitar, seperti kondisi alam yang buruk dll.

2. Fungsi Penafsiran

Dungsi ini dapat dilihat pendapat media mengenai kondisi masyarrakat yang terjadi. Media tidak hanya memberikan fakta melainkan juga memebrikan penafsiran/perspektif dengan tujuan media ingin mengajak para pembaca atau pemirsa/pendengar untuk memperluas wawasan dan membahasnya lebih lanjut dalam komunikasi jenis lain.

3. Fungsi Pertalian

Fungsi media idsini diartikan sebagai jembatan atau penghubung anggota masyarakat yang memiliki kesamaan kepentingan dan minat.

4. Penyebaran nilai-nilai

Fungsi penyebaran nilai-nilai oleh media atau efek dari media memang tidak terlihat begitu kentara, melainkan masuk dalam sikap individu atau khalayak dalam bersikap mengenai suatu fenomena atau suatu kejadian

5. Fungsi Hiburan

Fungsi hiburan seolah melekat dengan media. Tidak hanya cetak, elektronik juga menjalankan fungsi 
tersebut. Ada berbagai bentuk hiburan yang disajikan oleh media seperti olah raga, musik dan lainnya.

6. Fungsi Informasi

Media menyediakan informasi. Berbagai informasi disebarluaskan oleh media kepada khalayak. Meski informasi yang diperoleh khalayak bisa datang dari sumber lain, namun media massa tetap memberikan ruang untuk informasi.

7. Fungsi Pendidikan

Media memberikan pendidikan bagi pembaca/penonton atau pendengar. Pendidikan yang diberikan juga bermacam variasinya. Pendidikan yang disajikan oleh media massa tidak lepas dari keadaan masyarakat dan kebutuhan masyarakat.

8. Fungsi Mempengaruhi

Dari sajian media massa, seluruhnya mengandung unsur persuasif yang mempengaruhi masyarakat dalam bersikap.

9. DII

Kesemua fungsi tersebut tidak sepenuhnya dikendalikan oleh media, masyarakat sebagai konsumen atau khalayak media mempunyai kuasa penuh dalam menentukan apa saja yang menjadi pilihan. Berdasarkan pertimbangan kegunaan atau kebutuhan masyarakat, dengan sendirinya secara alami media masyarakat dapat menyeleksi media. Beberapa alasan pemilihan media yang dipilih masyarakat, dapat kita lihat seperti dalam catatan Elvinaro Erdianto dan Lukiati Komala (2004) yang melihat berdasarkan survei:

1. Saya ingin mengamati apa yang sedang pemerintah kerjakan

2. Saya ingin memahami apa yang terjadi di dunia

3. Saya ingin mengetahui apa yang sedang dialkukan oleh para pemimpin partai

4. Saya ingin belajar bagaimana melakukan sesuatu yang sebelumnya tidak pernah dilakukan

5. Saya ingin memuaskan rasa ingin tahu saya

6. Media membuat saya ingin belajar lebih tentang sesuatu

7. Media memberi saya ide-ide

Tentu masih banyak lagi alasan yang kita rasakan patut ditujukan kepada satu media yang dipilih. Untuk melihat perubahan akan efek dari kehadiran media massa secara umum dapat dilihat dari beberapa aspek berikut ini seperti yang dikatakan Elvinaro Erdianto dan Lukiati Komala (2004):

1. Efek Ekonomi

2. Efek sosial

3. Penjadwalan kegiatan sehari-hari

4. Efek hilangnya rasa tidak nyaman 
5. Efek Menumbuhkan perasaan tertentu

6. Efek Pesan

7. Efek Kognitif

8. Efek Afektif (suasana emosional, skema kognitif dan suasana terpaan Predisposisi Individual, behavioral).

Kembali pada media penyiaran diakui oleh para ahli penyiaran baik di Amerika hingga Asia mempunyai pengaruh yang besar terhadap perubahan masyarakat. Menurut Katz dan Wedell (1977) dalam Asia Sarji (1991) melabelkan bahwa media lektronik sebagai jendela dunia. Hal ini dilihat dari pengaruh yang diberikan kepada masyarakat yang menjadi khalayak dari media penyiaran.

Asiah Sarji (1991) menyebutkan bahwa perubahan sosial yang terjadi di masyarakat akibat dari munculnya penyelenggaraan penyiaran adalah bedasarkan besarnya peran penyiaran dalam pembangunan masyarakat di belahan dunia. Baik itu dalam mengentaskan kemiskinan, memberantas buta huruf hingga dalam pelayanan kesehatan hingga pengenalan teknologi pertanian.

Memang sejauh ini perubahan sosial yang dirasakan langsung oleh masyrakat sebagaimana yang dinyatakan Selo Soemardjan (Elly M. Setiadi \& Usman Kolip, 2011) perubahan sosial sebagai segala perubahan pada lembaga-lembaga kemasyarakatan di dalam suatu masyarakat, yang memengaruhi sistem sosialnya, termasuk di dalamnya nilai-nilai, sikap-sikap dan pola peri kelakuan di antara kelompokkelompok dalam masyarakat. Gillin dan Gillin mengatakan perubahan sosial sebagai suatu variasi dari cara-cara hidup yang telah diterima, baik karena perubahan-perubahan kondisi geografis, kebudayaan material, komposisi penduduk, ideologi maupun karena adanya difusi ataupun penemuanpenemuan baru dalam masyarakat. Secara singkat, Samuel Koening mangatakan bahwa perubahan sosial menunjuk pada modifikasi-modifikasi yang terjadi dalam pola kehidupan manusia. Modifikasi-modifikasi mana terjadi karena sebab-sebab internal maupun sebab-sebab eksternal.

Apabila melihat terjadinya perubahan setelah masyarakat menerima keberadaan teknologi penyiaran, baik dari segi nilai, material, sikap maupun caracara hidup. William Ogburn ungsionalisnya lewat teori menyatakan, bahwa perubahan teknologi akan berjalan lebih cepat dibanding dengan perubahanperubahan budaya, pemikiran, kepercayaan, nilai-nilai, norma-norma yang menjadi alat untuk mengatur kehidupan manusia. Teknologi biasanya 
menghasilkan kejutan budaya yang pada akhirnya memunculkan pola-pola perilaku yang baru, meskipun terjadi konflik dengan nilai-nilai tradisional (Elly $M$. Setiadi \& Usman Kolip, 2011: 618-619).

Perubahan yang terjadi dalam masyarakat sebagai akibat sentuhan teknologi menurut pemikiran Bourdieu (1984) dalam Irwan Abdullah (2009) menyebutkan lebih jauh bahwa informasi yang disalurkan melalui berbagai media (yang merupakan kekuatan paling nyata dari masyarakat modern) telah membentuk ideologi yang paling mendasar, yakni penegasan perbedaan dan kebebasan karena keragaman pilihan informasi memberi kemungkinan yang hampir tak terbatas untuk membangun perbedaan-perbedaan. Menurut Irwan Abdullah (2009) perbedaan merupakan tanda yang paling penting dalam kehidupan masyarakat modern dan media cetak maupun elektroniklah yang mensyahkan perbedaa ini dan pasar yang menyediakan pilihan barang yang tak terbatas dari sudut jenis dan kualitas.

\section{Radio Komunitas, Tumpuan Harapan Masyarakat}

Informasi mengenai eksistensi radio komunitas memang mulai menjadi tumpuan harapan semua orang datang dari Kementerian informasi dan Komunikasi hingga tahun 2012 terdapat
206 desa yang telah mendapat predekan desa informasi dengan basis radio komunitas, karena itu dari Kementerian informasi dan Komunikasi mempermudah perizinan dan konten dari radio komunitas. Alasan yang dikemukakan pihak kementerian adalah bahwa radio komunitas tidak berjalan seperti radio swasta yang mengedepankan unsur komersil, melainkan dioperasionalkan berdasarkan budaya dan agama.

Selain itu, kehadiran radio komunitas diyakini dapat membangun masyarakat di perbatasan, terpencil dan tertinggal seperti kesuksesan beberapa negara yang berhasil mengembangkan radio komunitas seperti Bangladesh, Mongolia dan Afrika. (Bambang Supriyanto,16 Mei 2012. diskominfo. tarakankota. go. id/artikel).

Dari tulisan di atas menunjukkan kepada kita bahwa penyiaran radio yang paling sederhana telah hadir di negeri ini dan telah mampu menjelaskan kepada dunia bahwa radio komunitas bukan sekadar siaran biasa. Tapi bisa mewarnai kehidupan berbangsa dan bernegara di Indonesia. Kehadiran radio Komunitas yang jauh dari kota mapun hiruk-pikuk dunia luar, tertnyata telah menjadi sorotan yang besar dari pemerintah.

Barangkali radio komunitas yang biasa disebut radio bawah tanah ini berawal dari kemiskinan pendidikan yang 
dienyam masyarakat, kemiskinan ekonomi dan sosial budaya ditambah dengan kemiskinan akses keterlibatan dalam pembangunan, sehingga masyarakat dari kelompok-kelompok kecil beramai-ramai bangkit dari keterpurukan tersebut untuk memulai sesuatu yang baru yang diharapkan bisa memfasilitasi kehidupan mereka agar lebih baik dan berguna.

Oleh itu tidak salah apabila kita sedikit melihat kondisi terkini dari radio komunitas. Keberadaan Rakom (radio Komunitas) yang menyajikan informasi dan hiburan untuk komunitasnya, menjadi media alternatif bagi daerah terpencil. Memasyarakat lebih bisa berinteraksi secara langsung. Tidak segan atau malu ketika berhadapan dengan radio komunitas. Hal ini didorong oleh faktor kepemilikan radio komunitas tidak seperti radio swasta, yang berorientasi pada nilai uang. Sementara radio Komunitas hadir berdasarkan keinginan masyarakat dalam komunitas tertentu yang tidak memikirkan keuntungan dalam operasionalnya.

Selain itu, ada beberapa alasan lain ketika radio komunitas hadir di tengah-tengah masyarakat, yakni adanya keinginan yang kuat untuk menjadi wadah masyarakat berkumpul kemudian membicarakan kebutuhan terkini mereka. Yang dijalankan secara sederhana, lebih bersifat terbuka, tidak sekadar diperuntukkan bagi komunitas, tetapi juga tentang komunitas yang melakukan sesuatu buat mereka sendiri, luwes dan tidak prosedural atau formal.

Kedua, esensi pengaturan kepengurusan radio komunitas dibentuk tidak atas dasar kemampuan pengelolaan yang termenej secara rapi layaknya radio swasta yang mempunyai kepengurusan yang lengkap. Radio Komunitas memungkinkan diurus beberapa orang saja dengan berbagai latar belakang tanpa melepaskan status pekerjaan mereka. Sebab, komposisi kepengurusan radio Komunitas adalah masyarakat sekitar yang notabene bekerja sebagai petani, ada nelayan, buruh pabrik, buruh lepas, ibu rumah tangga bahkan ada jadi korban PHK dsbnya. Dengan latar pendidikan yang berbeda-beda. Oleh itu, tidak ada perlakuan khusus bagi anggota radio komunitas, tidak ada diskriminasi dalam jalannya radio komunitas.

Ketiga dari aspek pembiayaan. Radio komunitas berdasarkan atas swadaya bersama, hasil rembukan atau berbagi beban kerja secara bersamasama tanpa ada target-target tertentu yang harus diikuti atau dipenuhi. Aspek modal yang terjadi pada radio swasta biasanya dan biasanya dikendalikan oleh pemilik saham lalu jadi pertimbangan besar dalam perhitungan maju dan mundurnya stasiun radio swasta. 
Sementara bagi radio komunitas bukan suatu kendala utama. Sebab posisi keuangan radio komunitas dipegang dan dikendalikan secara bersama. Ibarat pepatah "berat sama dijinjing ringan sama dipikul". Maka standar keuangan yang murah adalah menjadi dasar utama bagi operasional radio Komunitas.

Keempat. Dari aspek sumber daya manusia. Kehadiran radio Komunitas berupaya untuk maksimal dalam mengelola radio yang mereka punya tanpa sedikitpun berfikiran untuk memaksakan diri untuk tampil prima seperti yang dijalankan radio swasta, melainkan dijalankan sesuai dengan keadaan dan kemampuan dari masyarakat. Sehingga ketika berhadapan dengan persoalan peralatan atau materi siaran, kedua hal ini tidak terlalu dipusingkan. Karena itu, radio komunitas bersiaran mengikuti sebagian mengikuti naluri dan kemampuan yang ada.

Kelima, radio komunitas hadir dengan mengedepankan nilai-nilai budaya lokal yang melekat dalam masyarakat terutama dari tempat terlaksananya radio komunitas. Selain itu, radio komunitas juga memperhatikan lingkungan hidup mereka. Oleh itu, adat dan tradisi yang ada di sekitar radio komuitas menjadi salah satu unsur utama dalam isi siaran radio komunitas.
Hal ini senada dengan UndangUndang Penyiaran No 32 Tahun 2002 pasal 21 yang menyebut bahwa radio komunitas memang bersifat independen, tidak swasta, berdaya pancar rendah, jangkaun terbatas dan melayani kepentingan komunitasnya serta tidak untuk kepentingan propaganda bagi kelompok atau golongan tertentu.

Selanjutnya, di pasal 22 UndangUndang Penyiaran No 32 Tahun 2002 mengatur bahwa radio komunitas:

1. Tidak merupakan bagian dari perusahaan yang mencari keuntungan semata,

2. Untuk mendidik dan memajukan masyarakat

Namun diluar sana, jauh di tempat berdirinya radio komunitas, sebagian masyarakat belum mengerti bagaimana sebenarnya seluk-beluk radio yang mereka dirikan. Sebab tingkat bacatulis yang terbatas karena faktor pendidikan yang dimilik rendah, sehingga menghalangi masyarakat bisa berkomunikasi dengan dunia luar. Alhasil, keadaan ini menyebabkan hal-hal mengenai ketentuan maupun yang terkait dengan radio komunitasnya tidak menjadi persoalan diurus kemudian.

Jelasnya, radio komunitas berjalan mengikuti keterbatasan yang dimiliki masyarakat, adapaun tuntunan atau aturan yang disebut di atas dikemudian 
hari baru disentuh atau diperhatikan, itupun boleh jadi dikarenakan ada pihak luar yang membantu. Maksudnya, kemungkinan organsisasi masyarakat yang ada di sekitar radio komunitas seperti LSM.

Untuk memperjelas kita bagaimana geliat radio komunitas hadir di suatu tempat dapat berguna bagi masyarakat berikut ini penulis ketengahkan beberapa contoh radio komunitas di berbagai daerah dengan berbagai kerja sukses yang mereka perbuat untuk masyarakat.

1. Radio Komunitas Mandiri FM (Kabupaten Pekalongan)

Menjadi alat untuk membantu penyampaian materi pendidikan, penyuluhan kesehatan, mengadvokasi hak-hak dasar, menjadi sarana komunikasi dalam memobilisasi serta menjadi sarana informasi dan hiburan bagi masyarakat miskin. Tujuannya adalah agar masyarakat yang berada di bawah garis kemiskinan yang kurang peduli terhadap pendidikan lebih sadar dan lebih peduli agar tidak ada lagi warga yang anak-anaknya berpendidikan rendah dan hanya lulus sampai di pendidikan dasar. Lebih memilih bekerja untuk membantu ekonomi keluarga. Selain itu, rakom Mandiri
FM ini mendukung pemberdayaan ekonomi dengan memberikan infromasi tentang harga, akses pasar serta sarana promosi usaha masyarakat. (Nina Firstavina, www. P2kp.org/warta kita)

2. Radio Komunitas Marsinah FM (Kawasan Berikat Nusantara /KBN, Cakung Jakarta Utara) Radio komunitas Marsinah 106 FM ini adalah radio yang didiriak perempuan buruh untuk mensuarakan kesetaraan buruh lintas pabrik. Radio Marsinah memberikan informasi dan pengetahuan tentang diri dan hak perempuan buruh, informasi dari tokoh perempuan, kehidupan rumah tangga, anak dan lingkungan, tentang informasi kekinian di luar perburuhan, serta acara yang mendorong dan mewadahi keberanian, berekspresi dan mengadukan masalah.

3. Radio Lintas Merapi (Sidorejo Kemalang Klaten Jawa Tengah)

Radio ini mengajak masyarakat di sekitar lereng gunung merapi untuk lebih mencintai alam, menjaga lingkungan, mencintai satwa. Mengajak masyarakat mengenali ancaman gunung merapi dan tangguh, tanggap, siap menanggulangi ancaman Gunung 
merapi, yang bekerja sama dengan petugas gunung api merapi (BPPTK).

4. Radio Panagati (Sekitar sungai Code Jogjakarta)

Radio komunitas ini lahir berawal dari urung rembuk warga mengenai limbah rumah tangga, masalah pembangunan, gotong royong dll. Konstribusi radio komunitas Panagati adalah meberikan advokasi pembangunan Talud di pinggiran sungai Code melalui program interaktif radio. Program ini menghadirkan stake holder yang terkait dengan pemegang kebijakan hingga walikota (Agus Sudibyo 2004)

\section{E. Penutup}

Radio sebagai media komunikasi massa menjadi alternatif yang efisien dalam mengemas pesan. $\mathrm{Di}$ tengah derasnya arus informasi dan berlimpahnya teknologi saat ini, ada sebagian masyarakat yang belum dapat menikmatinya. Hal ini disebabkan rendahnya kemampuan masyarkat dari akses informasi.

Kehadiran media komunitas seperti radio komunitas yang berdiri di atas rumah penduduk, di tengah sawah atau di lereng gunung sekalipun telah warna baru bagi kehidupan masyarakat di tingkat komunitas.

Dikelola dengan sederhana, tidak berdasarkan teori penyiaran, radio komunitas hari ini kian berkembang, menjadi sarana penting yang bisa menghidupi masyarakat dari berbagai aspek. Namun hal tersebut tidak menyurutkan bagi pengelola radio komunitas untuk rendah diri lalu berhenti bersiaran. Sebaliknya radio komunitas semakin menunjukkan taringnya dengan menjaga kemurnian esensi penyiaran komunitas dengan tidak tercebur dalam kepentingan atau dominasi politik dan kekuasaan. Melainkan terus konsisten berkiblat kepada kepentingan masyarakat.

Radio komunitas memberikan konstribusi nyata dalam membantu masyarakat memperoleh infromasi, mengamati perkembangan setempat. Meski masih terbilang minim dari kata sempurna, kehadiran radio komunitas diakui telah membantu semua pihak, baik pemerintah dan masyarakat khususnya.

\section{F. Daftar Pustaka}

Agus Sudibyo, 2004. Ekonomi Media Penyiaran Agus Sudibyo. Jogjakarta: LkiS

Asiah Sarji. 1991. Penyiaran dan Masyarakat. Malaysia: Dewan 
Bahasa dan Pustaka Kementerian Pendidikan Malaysia

Bambang Supriyanto,16 Mei 2012. Kementerian Kominfo Permudah Izin Radio Komunitas. www.diskominfo.tarakankota.go.id /artikel) diakses tanggal 19 Januari 2013

Elly M. Setiadi dan Usman Kolip, 2011. Pengantar Sosiologi. Pemahaman Fakta dan Gejala Permasalahan Sosial: Teori, Aplikasi dan Pemecahannya. Jakarta: Kencana

Elvinaro Erdianto dan Lukiati Komala Erdiyana. 2004. Komunikasi Massa. Suatu Pengantar. Bandung: Simbiosa Rekatama

Irwan Abdullah .2009. Konstruksi dan Reproduksi Kebudayaan. Jakarta: Pustaka Pelajar

Ismahfudi, $\mathrm{MH}$, 2007. Radio Komunitas: Media Pemberdayaan Perempuan.

DIm Jurnal Studi Gender dan Islam.Vol 5 no. 4. Jogjakarta: PSW UIN Sunan Kalijaga Jogjakarta Morrisan. 2008. Manajemen Media Penyiaran. Strategi Mengelola Radio dan Televisi. Jakarta: Kencana Prenada Media Group

Nina Firstavina. 29 Mei 2013. Memberdayakan warga miskin Kok dengan Rakom. www. P2kp.org/warta kita)
Radio Komunitas Marsinah. www. Marsinahfm.wordpress.com. Diakses tanggal 3 Agustus 2012. Bersama-sama siaga wujudkan Ketangguhan. 17 April 2012. www. Merapi.combine.or.id. Diakses Agustus 2012. 